\title{
Rebuild or reform: regional and subregional architecture in the Pacific island region
}

Reconstruire ou réformer: l'architecture régionale et sub-régionale dans la région du Pacifique insulaire

\section{Tess Newton Cain}

\section{(2) OpenEdition Journals}

Electronic version

URL: http://journals.openedition.org/jso/7246

DOI: $10.4000 /$ jso.7246

ISSN: $1760-7256$

\section{Publisher}

Société des océanistes

\section{Printed version}

Date of publication: 15 June 2015

Number of pages: $49-58$

ISBN: 9782854301250

ISSN: 0300-953x

\section{Electronic reference}

Tess Newton Cain, « Rebuild or reform: regional and subregional architecture in the Pacific island region », Journal de la Société des Océanistes [Online], 140 | janvier-juin 2015, Online since 06 July 2015 connection on 03 May 2019. URL : http://journals.openedition.org/jso/7246 ; DOI : 10.4000/jso.7246 


\section{Rebuild or reform: regional and subregional architecture in the Pacific island region}

by

Tess NEWTON CAIN*

\begin{abstract}
To understand the current state of regional architecture in the Pacific requires an historical assessment of cultural, economic and political imperatives. Recent region-wide initiatives such as the review of the Pacific Plan (2013) have raised once again questions of what regional organizations should and can do to further development in Pacific Island Countries (PIC). Concurrently, we have seen the rise of sub-regionalism as a focus of economic and political activity, most notably in Melanesia. This paper considers the impact of the rise of sub-regionalism on the regionalism project overall to date and posits what might arise in the future.
\end{abstract}

KEYwords: (Pacific) regionalism, political economy, sub-regionalism, regional architecture, sovereignty

This paper examines the nature of the relationship between sub-regionalism and regionalism within the Pacific island region. The questions I consider are:

(a) What is the nature of regionalism in the Pacific and how has it changed over time?

(b) How can we expect regional and sub-regional groupings to develop and perform with reference to expected future changes?

(c) Why is it so difficult to engender political buyin for regional and sub-regional groupings and activities?

(d) How has France as a Pacific power contributed to the current state of (sub)-regionalism and how might this change in the future?

\section{RÉSUMÉ}

Afin de comprendre l'état actuel de l'architecture régionale dans le Pacifique, il est nécessaire d'en évaluer la nature historique, culturelle, économique et politique. De récentes initiatives régionales, telles que le dernier rapport sur le plan Pacifique (2013) ont une fois de plus soulevé la question de ce que les organisations régionales devraient et peuvent faire pour renforcer le développement des États insulaires du Pacifique (EIP). Parallèlement, nous assistons à l'émergence d'un subrégionalisme focalisé sur les questions politiques et économiques, tout particulièrement en Mélanésie. Cet article considère l'impact que le développement du sub-régionalisme a eu sur le projet régionaliste dans son ensemble et envisage les évolutions à venir.

MoTS-CLÉs : régionalisme (Pacifique), économie politique, subrégionalisme, architecture régionale, souveraineté

Elsewhere, this discussion is grounded firmly in terms of economic development stemming from the belief (and in some quarters this is essentially an article of faith) that the only feasible path to meaningful growth is through increased integration. My position is much more focused on historical and political economy factors, essentially as a complement to the economic scans presented by others.

I begin with an analysis of some of the key developments in the regional architecture of the Pacific. This section comprises a brief history of the development of that architecture and a summary of some of the attempts to reform and 
manage the proliferation of regional organizations. This is followed by an examination of the role of the Pacific Plan in relation to regionalism, with particular focus on the most recent review of this document undertaken in 2013. The third section examines the significance of sub-regionalism in the Pacific, in particular the growing presence of the Melanesian Spearhead Group. The penultimate section examines an essential tension between the regionalism project and national political imperatives and discusses how this affects interactions at sub-regional and regional levels. The article concludes with an exploration of future issues that are likely to arise and the opportunities and challenges they may present for the Pacific island region and sub-regions.

\section{Regional Architecture}

The proliferation of regional organizations, their inter-relations and effectiveness, both individually and overall, have been the subject of a great deal of debate and criticism over many years. The number of regional organizations has grown steadily since the 1950 s although there was a significant spike in this growth from the 1970s, which coincided with many Pacific island countries achieving independence (Hughes, 2013). There have been numerous attempts to reform the regional architecture but these have largely been in the nature of adjustments rather than radical reformulation such as the adoption of a "Pacific Commission" as some have advocated (Hughes, 2005). It is likely that there would be a certain degree of political resistance to making such a radical change even though on the surface it may appear to have much to recommend it in terms of efficiency and clarity.

More fundamentally, the use of a term "regional architecture" could be misleading as it implies a form that was designed in advance and built according to that design. The Pacific reality is that this is a term that we apply retrospectively to a vast array of organizations, programmes and projects, which have something of the "regional" about them:

"To the extent that there is a regional architecture in existence, it consists of a frame fitted around a collection of existing institutions and relationships, rather than a deliberate design that shaped the institutions and the way they relate to each other. " (Hughes, 2005: 6)

This in turn reflects what is evident from the literature in this regard; that the definition of "regionalism" is not easy to pin down. For example, Tarte (2014: 314) refers to "regionalism" as one aspect of the "regional order'. She also references the concept of "regionalism" as the label given to a network of regional organizations.
More recently, the review of the Pacific Plan in 2013 also identified that the term "regionalism" does indeed mean different things to different people (Morauta et al., 20013: 45) and went to some lengths to try and establish clarity about key terms such as "regional cooperation" and "regional integration". However, a footnote to the report contains a very telling comment:

"While the difference is conceptually clear, it is often difficult to draw a clear distinction between regional bodies that are pursuing regional integration and those that are facilitating regional cooperation. The reality is that many are doing both. " (Morauta et al., 2013: 46)

Beyond the technocratic discussions of regional organizations and the projects and programs they do (or sometimes do not) deliver, there lurks a rather nebulous sense of "Pacificness" that encompasses things such as cultural heritage, communal values and a complex relationship with the Pacific ocean. Perhaps the most significant and longstanding encapsulation of this is the oftcited "Pacific Way" that:

"asserted Pacific cultural values and practices, which in turn provided a basis for regional solidarity and empowerment. » (Tarte, 2014: 315)

Although the phrase, coined by the Rt Hon Ratu Sir Kamisese Mara, was originally formulated to have specific reference to the socio-political environment of Fiji it has gained and retained significant cachet more widely:

"I had coined the phrase 'The Pacific Way' and we felt we could speak from our own experience, insofar as Fiji was recommending continuing dialogue as a means of resolving differences on a basis of mutual understanding. » (Mara, 1997: 117)

All of these conceptualisations of regionalism have contributed over time to the complex and potentially confusing patchwork of organizations, activities and initiatives and their relative sway has varied over time as discussed in the next section.

\section{A Short History of Regional Architecture in the Pacific}

It is not possible here to provide the full story of how the regional architecture of the Pacific island region came to be what it is today. There are too many organizations to consider, of varying sizes and with a range of mandates from the very specific to the all-encompassing. However, by reference to some key developments, it is possible to illustrate some enduring issues that have influenced the debates about which regio- 
nal organizations are required, to do what, for whom in what way and with whose money.

Here, I take as my starting point the establishment of the South Pacific Commission in 1947. This body was made up of the then colonial powers of the region: Australia, France, New Zealand, United Kingdom, and United States of America. The rationale for its creation was

" partly based on ideas of pooling resources for research, information and training to promote development and eradicate disease. » (Fry, 2005: 91)

It is this mandate which informs the ongoing delineation of regional functions which characterises the (now) Secretariat of the Pacific Community (sPC) as a "technical" organization, not to be confused with the "political" body that is the Pacific Islands Forum (Newton Cain and Tukuitonga, 2014). When the South Pacific Commission was formed, it was not envisaged that indigenous Pacific leaders had any meaningful role to play in decision-making for the region:

"They were represented instead in the South Pacific Conference, a triennial meeting of Island leaders established in 1950 . The conference was a source of information for the commission on the particular concerns of Island countries, but without influence over the commission in any concrete way until decolonisation began and Island leaders were motivated to demand a more active presence in regional forums. » (Guthrie, 2013: 295)

The sPC now has 22 members, giving it the largest membership of the regional organizations. Its membership comprises sovereign states and dependent territories. Whilst it commenced operations in Sydney, it has had its Headquarters in Noumea since 1949.

The South Pacific Forum (which became the Pacific Islands Forum in 2000) was established in 1971. It was formed by Pacific leaders who were in the throes of guiding their people through the transition from colonies to independent nations. Its creation largely stemmed from the limitations placed on political discussion and decision-making by Pacific islanders within the South Pacific Commission.

«For some time we had felt that the constitution and procedures of the South Pacific Commission were too rigid, and that the attitudes of what may be called the administering powers were at best too paternalistic, and at worst arrogant and autocratic. " (Mara, 1997: 170)

Issues of concern that were not being given sufficient oxygen in that forum included testing of nuclear weapons by France and the USA and continuing struggles for independence in several Pacific territories (Morgan, 2013). Its current membership comprises 15 sovereign states (at the time of writing Fiji's membership has been reinstated although the current government has refused to rejoin unless Australia and New Zealand leave the group). Australia and New Zealand were originally accorded observer status but became full members soon after the grouping was established (Guthrie, 2013). New Caledonia and French Polynesia were made associate members in 2006. In 2010, New Caledonia sought to gain full membership but was unsuccessful (Morgan, 2013). The Pacific Islands Forum is supported by a secretariat located in Suva, Fiji. The "political" nature of the Pacific Islands Forum and its mandate was highlighted during the wave of "collective diplomacy", which was at its peak during the 1980s:

«While the Forum's campaign to support the decolonisation of New Caledonia did not influence France's explicit toward that territory, the success in gaining UN support on the re-inscription issue despite French lobbying, demonstrated what concerted diplomatic action could achieve in international fora. » (Fry, 2005: 97)

The most recent entrant into an already crowded landscape is the Pacific Islands Development Forum. Once again, the inherent political nature of how regional organizations come about and operate is writ large in this instance. When Fiji was suspended from the Pacific Islands Forum in 2009 it embarked on an aggressive programme of diplomatic and political engagement not only through a "look North" policy but also within the region. The Bainimarama regime instigated the "Engaging with the Pacific" dialogues and from this the Pacific Islands Development Forum was born, in 2013. The rhetoric of this grouping is situated in the importance of inclusivity and a determination to avoid domination by one or two key members such as is perceived to happen within the Pacific Islands Forum. The economic focus of this organization is avowedly on the blue-green economy but it is the domestic politics of Fiji and political relationships within the region and between regional powers and others (especially China) that will determine what its future will be, if indeed it has one (Dornan, 2013).

\section{Attempts to manage and reform regional architecture}

There have been numerous attempts to organise regional organizations to improve coordination between them, cut down on duplication (perceived and actual) and minimise waste of resources and effort. 
In 1988, an umbrella body was formed called the Council for Regional Organizations in the Pacific (CROP), although it was not a completely new creation having previously been incarnated as the South Pacific Organizations' Coordination Committee. The CROP currently comprises eight regional organizations: the Forum Fisheries Agency (fFA), the Pacific Islands Development Programme (PIDP), the Secretariat of the Pacific Community (SPC), the Secretariat of the Pacific Regional Environment Programme (sPrep), the South Pacific Tourism Organization (sPTO), the Pacific Power Association (PPA), the Pacific Aviation Safety Office (PASO) and the University of the South Pacific (USP). The role of the CROP is

" to improve cooperation, coordination and collaboration among the various intergovernmental regional organizations in the Pacific. " (PIFS, 2014)

The Secretary-General of the Pacific Islands Forum Secretariat (PIFS) is mandated as the permanent chair of the CROP.

More recently, a review of regional architecture was undertaken at the request of the PIFS (Hughes, 2005). This review was commissioned as a contribution to the "process surrounding and supporting the development of the Pacific Plan ${ }^{1 \text { " }}$ (Hughes, 2005: 5). At the time that this review was undertaken, there were ten CROP agencies and the review focused on five of them: the FFA, the PIFs, the South Pacific Applied Geoscience Commission (SOPAC) $)^{2}$ and the sprep. In 2005, this group of agencies was responsible for disbursing in excess of us $\$ 50$ million of external assistance per annum. The Hughes review was largely critical of the CROP considering it to be overly bureaucratic and having a tendency to act as some sort of "super" regional organization. Hughes identified a number of measures he felt would lead to greater collaboration, effectiveness and efficiency on the part of the "G5" as he termed the regional organizations on which he focused. However, his primary recommendation was that these agencies should become directorates under the overarching structure of a "Pacific Commission":

«A further proposal is therefore made for conversion of the G5 into a Pacific Commission, by amalgamating their operations and funding arrangements under a unified management structure that would internalize and eliminate inter-G5 barriers. The separate (but overlapping) memberships and political character of the Forum and the Pacific Community would be preserved, but they would be served by a unified Secretariat and Directorates forming the Pacific Commission. Over time the Forum and the Community would inevitably move closer together until eventual- ly a form of merger becomes possible that would be acceptable to all members. This approach is preferred by the report as likely to produce the more efficient and effective arrangements for strengthening regional cooperation. » (Hughes, 2005: 3)

Subsequently, in 2007, a process called the Regional Integration Framework (RIF) commenced with the objective of reducing the number of regional organizations and enhancing integration and cooperation at regional level (Ivarature, 2013). The basis of this process was a report (Tavola et al., 2006), which disagreed with Hughes' suggestion for a Pacific Commission. The Hughes report informed this new review but was considered flawed because of lack of widespread consultation. Hughes' recommendations as to the establishment of a Pacific Commission were considered problematic:

«It was felt that the proposed dual governance arrangements were unworkable because one governing body would be subservient to the other on the key matters of approving budgets and appointing a Chief Executive Officer. As a result, according to this line of reasoning, decision-making would be unequal and the status of territories, France and the United States of America as full members of the Pacific Community and other regional organizations would be jeopardized. " (Tavola et al., 2006: ii)

This review concluded that it was preferable to maintain the avowed separation between the "political" pillar of regional architecture as embodied by the PIFs and the "technical" pillar spearheaded by the SPC. A third pillar was designated to bring together all of the regional organizations concerned with education and/or training. Further to this review, the number of CROP agencies was reduced from ten to eight.

There have also been criticisms of the regional architecture, which might be described as more philosophical in nature:

"The regional project has been seen as illegitimate because it has been too state-centric, too maledominated, or dominated by larger countries such as Fiji. In general terms, there has been a tension between those who see the need for an openingup of regional governance to include civil society, sovereignty movements and non-independent territories and those who support a state-centric regional community. » (Fry, 2005: 103)

These concerns were echoed in several of the public submissions that were made to the most recent review of the Pacific Plan (see below). An analysis of those submissions revealed that whilst there were many calls for more and better integration and cooperation between existing regio-

1. The significance of the Pacific Plan for regionalism and regional architecture is examined below.

2. This agency has since been brought within the SPC. 
nal organizations, there was not a great deal of appetite for creating new ones. However, a strong theme that did emerge was the need for existing regional organizations, and especially those at the apex of the structure: the Pacific Islands Forum and its Secretariat (PIFS, 2013) to be more inclusive. Of particular concern was the apparent lack of access to these bodies for civil society organizations, both national and regional.

In addition to these pan-Pacific attempts at reform of the overall architecture, there have been more targeted activities in relation to specific organizations or agencies within the overall scheme. These have had mixed fortunes in terms of their acceptance and achievements. Both USP and SPC have undergone wholesale strategic reviews in recent years and these have largely been welcomed and recognised as providing significant value. However, a review of the PIFS in 2012 did not fare as well. Although a copy of the review was leaked, it has yet to be released officially. More significantly, the regional leadership has failed to take seriously the findings of that review, some of which were framed in very trenchant terms (Dornan, 2012). When the report was leaked, the Pacific Islands Forum indicated that it would defer addressing its recommendations until such time as the 2013 review of the Pacific Plan was concluded (see below). That time has now come but no mention of this review, its recommendations and implications has yet been made.

In late 2014, the foreign ministers of Australia and Fiji announced that they would be convening a review of the Pacific regional architecture. This announcement was made without reference to any of the other countries that have a stake in this type of activity. Although there has been some small welcome of this initiative (Brien, 2014), it is largely considered to be neither warranted nor appropriate (Dornan and Newton Cain, 2014b).

\section{The Pacific Plan ${ }^{3}$}

Unsurprisingly, there is an important link between the various regional organizations and the Pacific Plan, a framework document designed to guide cooperation and integration between members of the Pacific Islands Forum. Indeed, one of the functions of the CROP is to provide a mechanism for member organizations to monitor and report against their implementation of the Pacific Plan. The Pacific Plan originated with at the "Auckland Declaration" made at the Pacific Islands Forum meeting of Leaders in 2004:
" Leaders believe the Pacific region can, should and will be a region of peace, harmony, security and economic prosperity, so that all its people can lead free and worthwhile lives. We treasure the diversity of the Pacific and seek a future in which its cultures, traditions and religious beliefs are valued, honoured and developed. We seek a Pacific region that is respected for the quality of its governance, the sustainable management of its resources, the full observance of democratic values, and for its defence and promotion of human rights. We seek partnerships with our neighbours and beyond to develop our knowledge, to improve our communications and to ensure a sustainable economic existence for all. » (PIF, 2004)

Since its adoption in 2005, the Pacific Plan has been subjected to a great deal of criticism. Some of this criticism stems from the fact that rather than it being a springboard for new initiatives focused on cooperation and integration, it was treated as something of a catch-all for existing activities and projects being undertaken by regional organizations. Another criticism of the Pacific Plan is that is largely donor driven with too much power vested in Australia and, to a lesser extent, New Zealand rather than ownership being exercised by Pacific island countries. Another significant criticism of this document is that it is too prescriptive and has too many priorities and objectives. Its prescriptive nature is exemplified by reference to pooling of service delivery within the region, with specified activities delineated rather than a process by which appropriate options might be identified and explored (Dornan and Newton Cain, 2014a).

The Pacific Plan was envisaged as a "living document" and has been subject to more than one review since its adoption. The most recent review was undertaken in 2013. An eminent group, led by Sir Mekere Morauta (a former prime minister of Papua New Guinea) and assisted by two international consultants, undertook extensive consultations. They visited each of the fourteen member countries and the two associate members (New Caledonia and French Polynesia). They also invited public submissions and received in excess of 70 of those. The relationship between the Pacific Plan and the agencies and organizations that constitute the regional architecture, was identified as a key focus of the review process:

" The Review was, among other things, asked to consider governance and priority-setting, and to what extent the regional institutional architecture supports the strategic directions of the Plan. » (Morauta et al., 2013: 12)

In presenting its "diagnosis" further to consultations, the review team encapsulates the in- 
herent and abiding refrain of Pacific regionalism and the arising debates: this is essentially a political process and not a technical one:

"The place of the CROP agencies in prosecuting regionalism is an interesting one from a political perspective. Their activities are almost invariably "in line with" the Pacific Plan, and they are a necessary resource for its implementation. There is therefore an assumption that the CROP agencies are the embodiment of regionalism: that regionalism is the product of the CROP agencies' work. However, the Review takes the view that regionalism is in the first instance a political, not technical, process. This Review did not recognise such a robust political dialogue about regionalism. While cooperation at a technical level is relatively good across the Pacific, hard political choices being made about economic integration and the future of the Pacific are much more difficult to pinpoint. " (Morauta et al, 2013: 17).

In terms of reimagining Pacific regionalism and the mechanisms by which it can be achieved, the review has identified a number of ways in which relevant institutions and processes should be overhauled. They include:

- Supporting political conversations rather than technical ones;

- Identifying and developing "game-changing political initiatives" to actively prosecute regional cooperation and integration;

- Enhancing operational efficiency by way of "more predictable and sustainable, and less distortionary" funding;

- Improving governance so that "the totality of effort constitutes the strategically right thing to do to achieve the aspirations of the Pacific's leadership as regards regionalism" (Morauta et al., 2013: 21-22).

One of the key recommendations of that review was that the Pacific Plan should adopt and promote a clear public policy process to facilitate the identification, investigation, implementation and evaluation of regional activities rather than setting out a list of objectives to be achieved as was previously the case (Dornan, 2014). This recognises and addresses a longstanding criticism that the Pacific Plan had too many objectives to the point that its overarching strategy had become obscured.

The result of the review was that the Pacific Plan was reformulated as a "Framework for Pacific Regionalism". This Framework was endorsed at the Pacific Islands Forum leaders meeting in Palau at the end of July 2014. Although the Framework addresses issues of regionalism that go beyond pooling of service delivery, it does maintain a commitment to identifying and progressing activities that aim to deliver services regionally as a means of remedying national deficits.
However, a significant change, which is to be welcomed is the move away from a list of priorities as occurred with the Pacific Plan to the development of a process by which priorities can be identified, researched, modelled prior to reference to the appropriate level of decision-making.

\section{The Rise and Rise of Sub-regionalism}

The establishment of sub-regional groupings is not a recent phenomenon in the Pacific island region. However the level of activity at the subregional level has recently increased in a number of spheres including trade, economic integration and political activity. There are three regional sub-groupings, which generally correspond with three broadly recognised cultural groupings in the region. Each of these groupings has a membership comprising both sovereign states and other entities that are "non-sovereign".

In the northern Pacific (Micronesia) there is the Micronesian Chief Executives' Summit, which was convened for the first time in 2003. This group comprises the political leadership of the Commonwealth of the Northern Marianas, the Territory of Guam, the Federated States of Micronesia and its States (Yap, Kosrae, Pohnpei and Chuuk), the Republic of the Marshall Islands and Palau. The group has established the "Micronesia Challenge", which has a very strong focus on issues relating to the environment and management of natural resources:

"The Micronesia Challenge is a commitment by the Federated States of Micronesia, the Republic of the Marshall Islands, the Republic of Palau, Guam, and the Commonwealth of the Northern Marianas Islands to preserve the natural resources that are crucial to the survival of Pacific traditions, cultures and livelihoods. The overall goal of the Challenge is to effectively conserve at least $30 \%$ of the near-shore marine resources and $20 \%$ of the terrestrial resources across Micronesia by 2020. » (Micronesia Challenge, 2010-12)

The Polynesian Leaders' Group is made up of the leaders of eight states and territories. They are American Samoa, Cook Islands, French Polynesia, Niue, Samoa, Tokelau, Tonga, and Tuvalu. This group was established largely as a response to the growing presence of the Melanesian Spearhead Group (see below). It is the least active of the three groupings with its focus being more about establishing and maintaining cultural ties rather than active economic or political endeavours.

The Melanesian Spearhead Group (MSG) was established in 1988 and gained recognition as an international organization in 2007. It comprises the sovereign states of Fiji, Papua New Guinea, Solomon Islands and Vanuatu plus the Front de 
libération nationale kanak et socialiste (FLNKS), a pro-independence movement from New Caledonia. The FLNKS took over the chair of the MSG during 2013. The MSG is generally recognised as the most established and active of the subregional groupings. It has a secretariat located in Port Vila, Vanuatu and, in recent years, has been increasingly active both politically and economically. The state members have signed both a free trade agreement and a skilled movement scheme to allow for labour migration within the sub-region. At its most recent summit in 2013, the MSG took the innovative step of establishing a department of peacekeeping operations (DPKO) to explore opportunities for providing military personnel from group members to UN peacekeeping missions elsewhere in the world. In the political sphere, the MSG has established an FLNKS unit within its secretariat. This unit has taken on progressing a number of initiatives that exist under the Noumea Agrement that were previously within the remit of the Pacific Islands Forum Secretariat. The MSG through its secretariat has also facilitated visits by Kanaky public servants to Timor Leste to get a sense of how to go about establishing a new state should the time come when New Caledonia becomes an independent country.

The confidence and apparent acceptance of the MSG is illustrated by the moves it has made to set up what might be termed "sub-regional architecture". Leaders' summits are a well-established feature and, as has already been noted, a secretariat has been established. There are regular meetings of ministers and officials which are smaller versions of structures and processes utilised by the Pacific Islands Forum. There is a conference of MSG chiefs of police and plans to convene similar forums for chief justices and speakers of parliaments from within the sub-region. Not only does this require careful management by the MSG but it also raises questions for regional organizations as to the when, where and how engagement between sub-regional and pan-regional agencies:

"The prospect of MSG institutions proliferating could be problematic for region cooperation, but it is not improbable. These possibilities will have to be factored in to the promotion of Pacific regional cooperation and the design of regional activities. " (Hughes, 2013: 12)

Another form of sub-regionalism that can be observed arises in the realm of pooled service delivery. In recent research, it was noted that there were some serious challenges to the delivery of "public goods" on a pan-regional basis, with a number of these being closely linked to issues of political economy. These obstacles may be more easily overcome when working at the sub-regional level (Dornan and Newton Cain, 2014a). Pooled service delivery at the sub-regio- nal level does not have to be formulated by reference to geographic proximity. It is possible that countries may come together to pool resources or bulks procure services with reference to a shared economic or development interest. The Parties to the Nauru Agreement is a good example of this type of grouping. The members of this organization are particularly concerned with the management of fisheries in the region and appear to have gained more traction in this space than the larger, Forum Fisheries Agency. Another area that might lend itself to shared resources is in relation to managing extractive industries. Countries such as PNG, Solomon Islands and Fiji may see some benefit in establishing a pooled resource of technical, regulatory and other expertise to maximise positive impacts (and minimise negative ones) of resource extraction.

However, one of the biggest challenges in terms of progressing initiatives either at sub-regional or regional level arises in the space of making these arenas relevant to political leaders whose primary and possibly sole preoccupation is the domestic agenda. This is explored in the following section.

\section{The ongoing tension between national political interests and the "regionalism" project}

Whilst it would appear to be self-evident that the small countries of the Pacific must benefit from working together and establishing agencies and mechanisms to do so, it is important to take account of some very significant political economy factors that militate against this. They are exemplified within the context of pooled service delivery (Dornan and Newton Cain, 2014a), where Air Pacific was perhaps the most obvious example of theory not translating into practice:

"There was a perception among Islands states that Air Pacific had not served the interests of all its shareholding states equally, in addition to which, nationalist aspirations, particularly the prestige associated with the operation of a national carrier, had seemingly overridden aspirations for integration in the aviation sector. »(Guthrie, 2013: 296)

Similar tensions arise in relation to the acceptance or otherwise of regional organizations. The political imperatives to share the benefits of establishing such bodies have led to them being dispersed across the region. Again, whilst this may not be the most efficient way of locating organizations that would no doubt benefit from being in close proximity to each other (not least by cutting down on travel costs) there are significant political reasons as to why that is not the case. Issues of sovereignty, or the perceived loss of it 
associated with regionalism, are significant. This is not surprising given the very recent emergence from colonial rule of the countries of the region. More practically, the capital city in which a regional organization is located accrues economic benefits including generation of employment and local procurement of goods and services. For a number of reasons, Suva has long been seen as the 'natural home' of regional organizations. This has led to a certain amount of jealousy among other countries who feel that Fiji is benefitting disproportionately. This criticism has been particularly marked with reference to USP:

"Around four-fifths of usp's full-time students are from Fiji, significantly in excess of Fiji's share of member PICTS' population ${ }^{4}$, and Fiji citizens predominate in the academic and administrative staff. The Suva campus is a major source of incomes to Fiji through employment, purchase of goods and services and payment of taxes by individuals and UsP itself. The concentration of the benefits of USP in Fiji has long attracted adverse comment in the region. " (Hughes, 2005: 16)

In both of these scenarios an essential tension remains. The regionalism project has no political currency at national level. In many Pacific island countries, politics are avowedly and doggedly local in nature. Votes are secured (by various means including purchase) by reference to local priorities, with the majority of political allegiances being based around (extended) family or cultural ties. This means that where policy decisions are discussed they rarely fix on national issues and never on regional ones. Pacific island leaders may well issue statements that appear to be commitments to more or better regional cooperation whilst sequestered on one remote island or another (and there is no shortage of those in the region). But on returning to their homeports and the realities of managing domestic politics and polities, enthusiasm wanes rapidly. Where regional projects or regional organizations are discussed (and generally they are just not mentioned at all), the discussion is often couched in terms of protecting sovereignty or lobbying for a regional project or organization to be domiciled in a given country (Hughes, 2005).

\section{Current and Emerging Issues}

The issue of self-determination is one that has coloured numerous developments in the realm of regionalism and sub-regionalism. As has been discussed above, the Pacific Islands Forum had self-determination for Pacific islanders at its heart from its inception. The enduring wish for independence throughout the region is continued in the presence of the flnks in the Melanesian Spearhead Group and the ongoing process associated with negotiating possible membership for a non-sovereign group to represent the Melanesian people of West Papua. The application for membership by the United Liberation Movement of West Papua (ulmwp) will be considered at the msg Leaders' Summit in mid2015. This represents a critical juncture for the group as it seeks to negotiate a very tricky path between the wish to promote self-determination for West Papua (voiced most loudly by Vanuatu but increasingly volubly within Melanesian civil society) and ever-deepening military, diplomatic and economic relationships between msg members (especially Fiji and Papua New Guinea) and Indonesia (Webb-Gannon \& Elmslie, 2014).

A preoccupation with self-determination was also reflected in the re-entering of French Polynesia on the un List of Non-Self Governing Territories further to a motion put before the un General Assembly in 2013. That motion was sponsored by Nauru, Solomon Islands and Tuvalu. This year is a key milestone for the process of self-determination for New Caledonia as envisaged by the Noumea Accords. How the status of New Caledonia is resolved in the next few years may be instructive in terms of future determinations, such as for the future of Bougainville:

"New Caledonia led the way into the decades of preparation; now it must demonstrate if such a process can ever be finalised. Whether success or failure, what France does in New Caledonia will have a huge demonstration effect for PNG and Bougainville. And that resolution will say much about whether France can become more than an outside power in the South Pacific, defined as much by ambiguity as any ambition. » (Dobell, 2013)

Metropolitan powers, including France, will need to work out how, if at all, to engage with sub-regional groupings. As discussed above, the most significant of these organizations is the MSG and the status accorded to the FLNKS within that group is already significant and will become more so as the process of transfer of sovereign powers progresses under the Noumea accord. But it will be even more significant should that process stall or founder. Congressional elections were held in May 2014. These elections are significant, as the resulting Congress will play a significant role in the next stage of implementation of the Noumea. Between 2014 and 2018 the Congress can move (by a 3/5 majority) to a referendum on the transfer of remaining sovereign powers from France to the Pacific territory. 
How peak regional organizations engage with non-sovereign territories will also continue to be significant and may not always be straightforward. Mention has already been made of the inclusion of New Caledonia and French Polynesia in the consultation process associated with the 2013 review of the Pacific Plan. However, it is not clear whether this should be taken as an indication of an intention on the part of the Pacific Islands Forum to upgrade the status of these territories from associate to full membership. In some quarters, there has been robust criticism of the level and nature of engagement with nonsovereign territories (including the French ones) by CROP agencies:

"A decade ago, the Forum Eminent Persons Group led by Sir Julius Chan saw closer integration between the Pacific Islands Forum and the Us and French territories as a crucial part of their vision for the region. Sadly, the future status of the Pacific territories was effectively dropped from successive revisions of the Plan and ignored in annual Pacific Plan declarations issued by Forum leaders - the latest Pacific Plan Annual Report (2012) makes no mention of the Pacific territories. » (Maclellan, 2013: 1)

The 2013 review of the Pacific Plan does not make any recommendation as to whether the membership of the Pacific Islands Forum should be extended to include territories that are nonself governing. Whilst it would be improper for a review team to make recommendations of this type one way or another, the review team has noted the flavour of comments and recommendations made by those with whom they consulted on this issue. The report refers to a sense that the key debates that framed the establishment of the Pacific Islands Forum (most notably the push for independence and the campaign for a nuclear free Pacific) have now been largely superseded:

"The contemporary debate about regionalism has rather less intrinsic association with selfdetermination. Most of the issues being debated in contemporary Pacific regionalism (trade and transport, for example) are entirely within the mandate of even the non-self-determining territories to resolve, and regionalism would be better served by fully including, not excluding, such territories in the debate and in its implementation. " (Morauta et al., 2013: 78)

The elections in Fiji during September 2014 have already had an impact at regional level and this is likely to continue. Fiji's reluctance to rejoin the Pacific Islands' Forum has already been referenced, as has the Australia-Fiji initiative to review the regional architecture in early 2015. Although Fiji utilised alternative political and diplomatic channels (including chairing the MSG from 2010 to 2012) to maintain and possibly enhance her international standing in the period since 2009 (when she was suspended from the PIF), the leadership is obviously keen to reclaim her previous role of regional leader. However, the prevailing environment has changed most notably in the rise of Papua New Guinea in this space, an avowed policy imperative of Peter O'Neill, prime minister of that country (Hayward-Jones and Newton Cain, 2014). In the last few years PNG has become a bilateral and regional development partner and lobbied hard and successfully for Dame Meg Taylor (a former PNG diplomat) to become Secretary General of the PIFS in 2014. Ongoing diplomatic tensions between these countries are already causing headaches for the MSG and may cause disruption at the wider regional level.

The nature of Pacific regionalism is ever changing and the future may well bring as much iteration as we have seen in the past. The regionalism project is often couched in economic terms with a strong focus on how Pacific island countries can overcome tyrannies of distance, diseconomies of scale and other vulnerabilities. However, issues of history, politics and culture are and will continue to be key determinants of how that project does or does not proceed.

\section{Acknowledgement}

The views contained in this paper are mine alone, as are any errors or discrepancies. I would like to thank the peer reviewer and Dr Matthew Dornan of the Development Policy Centre for their comments and feedback on earlier drafts.

\section{BIBLIOGRAPHY}

Bergin Anthony, 2014. France: Australia's regional partner? The Strategist (http:// www.aspistrategist.org.au/france-australiasregional-partner/?utm_source $=$ rss\&utm medium $=$ rss\&utm_campaign $=$ france-australias-regional-partner\&utm_reader=feedly, accessed 22/03/14).

BrIEn Derek, 2014. Re-casting Pacific regional architecture, Pacific Politics (http://pacificpolitics.com/2014/11/re-casting-pacific-regional-architecture/, accessed 25/11/14).

Dobell Graeme, 2013. France in the Pacific: ambiguity and ambition, The Strategist (http:// www.aspistrategist.org.au/france-in-the-pacificambiguity-and-ambition/, accessed 22/03/14).

Dornan Matthew, 2012. Swept under the pandanus mat: the Review of the Pacific Islands Forum Secretariat needs to be taken seriously, 
Devpolicyblog (http://devpolicy.org/swept-under-the-pandanus-mat-the-review-of-the-pacific-islands-forum-secretariat-needs-to-be-taken-seriously-20120920/, accessed 22/03/14).

—, 2013. Pacific Islands Development Forum launch in Fiji, Devpolicyblog (http://devpolicy.org/in-brief/pacific-islands-developmentforum-launch-in-fiji-20130813/, accessed 22/03/14).

-, 2014. Pacific Plan Reviewed: what next? Devpolicyblog (http://devpolicy.org/pacificplan-reviewed-what-next-20130204/, accessed 22/03/14).

Dornan Matthew and Tess Newton Cain, 2014a. Regional Service Delivery Among Pacific Island Countries: An Assessment, Asia and the Pacific Policy Studies 1, 3, pp. 541-560.

-, 2014b. Another review of the Pacific regional architecture is neither warranted nor appropriate, Devpolicyblog (http://devpolicy. org/another-review-of-the-pacific-regionalarchitecture-is-neither-warranted-nor-appropriate-20141111-2/, accessed 25/11/14).

Fisher Denise, 2013. France in the South Pacific: Power and Politics, Canberra, ANu Press.

Fry Greg, 2005. 'Pooled Regional Governance' in the Island Pacific: Lessons from History, in S Chand (ed.), Pacific Islands Regional Integration and Governance, Canberra, Asia-Pacific Press, pp. 89-104.

—, 2015. Recapturing the Spirit of 1971: Towards a New Regional Political Settlement in the Pacific, State, Society \& Governance in Melanesia Discussion Paper 2015/3 (http:// ips.cap.anu.edu.au/sites/default/files/DP2015-3-Fry-ONLINE.pdf).

Guthrie Karina, 2013. Aviation Regionalism in the Pacific, The Journal of Pacific History 48, 3, pp. 294-308.

Hayward-Jones Jenny and Tess Newton Cain, 2014. Pacific island leadership: PNG steps up, The Interpreter (http://www.lowyinterpreter. org/post/2014/08/28/Pacific-island-leadership-PNG-steps-up.aspx, accessed 26/11/14).

Hughes Anthony, 2005. Strengthening Regional Management: A Review of the Architecture for Regional Co-operation in the Pacific, consultative draft for the PIFs.

—, 2013. The Pacific Plan: vague purpose, shaky ownership, fractured implementation, Devpolicyblog (http://devpolicy.org/the-pacificplan-vague-purpose-shaky-ownership-fractured-implementation-20130226/, accessed 11/03/14).
Ivarature Henry, 2013. Regionalism: Performance and Promise, in D. Hegarty and D. Tryon (eds), Politics, Development and Security in Oceania, Studies in State and Society in the Pacific 17, ANU E-Press, pp. 179-194.

Maclellan Nic, 2013. The Pacific Plan and Non-Self Governing Territories, submission to the Pacific Plan Review 2013.

MacqueEn Nigel, 1989. Sharpening the Spearhead: Subregionalism in Melanesia, $\mathrm{Pa}$ cific Studies 12, 2, pp 33-52.

Mara Rt Hon Ratu Sir Kamisese, 1997. The Pacific Way: A Memoir, Honolulu, University of Hawai'i Press.

The Micronesia Challenge, 2010-2012 (www. micronesiachallenge.org, accessed 10/03/14).

Morauto Mekere, Peseta Noumea Simi, Redley Killion, Peter Bazely and Nick Poletti, 2013. Pacific Plan Review 2013, vol. 1: Report to Pacific Leaders (http:// www2.kobe-u.ac.jp/-alexroni/TR2014\%20 readings/2014_10/Review\%20Rpt\%20 2013\%20Vol\%202_final4Feb.pdf).

Morgan Wesley, 2013. The Political-Economy Dynamics of Regionalism in the Pacific: Challenges and Opportunities in the $21^{\text {st }}$ Century (Unpublished manuscript), London, Commonwealth Secretariat.

Newton Cain Tess and Colin Tukuitonga, 2014. What does the future hold for SPC? An Interview with Colin Tukiotonga, Devpolicyblog (http://devpolicy.org/what-does-the-future-hold-for-SPC-an-interview-with-colintukuitonga-20140320/, accessed 20/03/14).

PIfs, 2014. Digest of Public Submissions Made to the Pacific Plan Review 2013, Suva, PIFs.

-, 2014. Council of regional organizations in the Pacific (CROP) (http://www.forumsec. org/pages.cfm/about-us/our-partners/ crop/?printerfriendly=true, accessed 18/03/14).

TARTE Sandra, 2014. Regionalism and Changing Regional Order in the Pacific Islands, Asia and the Pacific Policy Studies 1, 2, pp. 312-324.

Tavola Kaliopate, Makurito BaAro, Lucy Bogari, Lourdes Pangelian, Adrian Simcock and Epa Tuioti, 2006. Reforming the Pacific Institutional Framework (http://www.sopac. org/sopac/docs/RIF/07_RIF\%20study, $\% 20$ final_Tavola\%20et\%20al.pdf).

Webb-Gannon Camellia and Jim Elmslie, 2014. West Papuan Heartache? Indonesia's Melanesian Foray, The Asia Pacific Journal 12, 47, 3, 10 p. (www.japanfocus.org/-CamelliaWebb_Gannon/4225). 